\title{
MODERN TECHNOLOGIES IN THE FIGHT AGAINST IDEOLOGICAL, IDEOLOGICAL AND INFORMATION ATTACKS IN THE CONTEXT OF GLOBALIZATION
}

\author{
Nargiza Sayidumarovna Hasanova \\ Graduate Student, Tashkent State Pedagogical University Named After Nizami, Uzbekistan
}

\section{ABSTRACT}

The process of globalization, its complexity and diversity, the process of globalization, which affects the national culture and spirituality, penetrating deeper and deeper into the human world, the formation of concepts of globalization, the pedagogical impact of modern debates on globalization. mystery tools are illuminated.

KEYWORDS:- Globalization, threat, spirituality, enlightenment, trend, development, independence, "popular culture", idea, information crisis.

\section{INTRODUCTION}

After gaining its independence, the Republic of Uzbekistan, like all other spheres, has undergone significant changes in the field of science. Speaking about the education and future of the younger generation, President of the Republic of Uzbekistan Shavkat Mirziyoyev said: To do this, we must, first of all, nurture a new generation of knowledgeable and qualified personnel who will emerge as enterprising reformers, think strategically. That is why we have started to reform all levels of education, from kindergarten to higher education. In order to raise the level of knowledge, not only young people, but also members of our society, first of all, education, higher education. need naviyat. Where there is no knowledge, there is backwardness, ignorance and, of course, straying from the right path. As the sages of the East say, "The greatest wealth is intelligence and knowledge, the greatest heritage is a good upbringing, the greatest Poverty is ignorance! "Therefore, for all of us, the acquisition of modern knowledge, true enlightenment and high culture must become a constant vital need [1,]" in today's globalization, the education of the younger generation is more important than ever. The period itself shows that it is relevant.

The Republic of Uzbekistan has made great strides in its short-term reforms. Today, the world is undergoing a process of rapid globalization, which is increasingly capturing the world of humanity and penetrating deeper into their lives, influencing the national culture and spirituality. As a result of this process, there is a clash of different civilizations and cultures, which causes a number of problems and 
CURRENT RESEARCH JOURNAL OF PEDAGOGICS 2(6): 131-136, June

2021 DOI: https://doi.org/10.37547/pedagogics-crjp-02-06-25

ISSN 2767-3278

(C)2021 Master Journals

\section{Crossref do) 81 Google}

Accepted 25th June, 2021 \& Published 30 $0^{\text {th }}$ June, 2021

threatens the spirituality of nations. Deeply aware of the positive and negative aspects of this process, the first President of the Republic of Uzbekistan Islam Karimov in the third chapter of his book "High spirituality is an invincible force" focused on "Globalization processes and spiritual threats." Islam Karimov describes the phenomenon of globalization in this play as follows: "This process expresses the formation of a completely new economic, socio-political, natural and biological global environment, as well as the transformation of existing national and regional problems into global problems. is [2,]".

Now, let's define what the word globalization is, or rather, its original lexical meaning. The term "global" in French means global - "general", in Latin - globus. globalization can be interpreted as an "all-encompassing" term. The emergence of global problems has led to the formation of concepts of globalization. Even as a result of this process, global studies have emerged that teach universal problems. At the heart of this science are environmental, economic, social and political issues.

Nowadays, the education of high spirituality in young people is the study of the main aspects of all historical and cultural riches, the development of our national culture, periods, laws of development, the great figures who created spiritual riches, the heritage of wise writers, the achievements of other cultures. they are required to conduct extensive educational work on these issues in order to be respected. This will be a leading factor in the development of the young generation in the conditions of independence, who are well aware of the national cultural heritage, full of national pride and patriotism, and aware of the level of cultural development in the world.

Globalization involves integrated processes. Commenting on the issue of globalization, A.
Ochildiev said that "... in the most general sense, globalization means, on the one hand, that a particular event, process covers all regions, states and the whole Earth, and on the other hand, affects the fate of mankind." [3,].

Danilov-Danilyan V.I. "Globalization is more a matter of historical paradigm than logic. There is no clear and concise analysis of the interrelationships of globalization "[4,]. From the above definitions, it is clear that the process of globalization is characterized by its complexity and diversity. That is why S. Otamuratov said, “... views on the concept of globalization continue to be diverse. This is natural. Because it has different possibilities in space and time, and its influence on the change of the world reveals new possibilities [5,]".

Professor A. Katsovich describes the process of globalization and the emergence of new descriptions of the world economy: "Globalization can be defined by the intensification of economic, political, social and cultural ties across borders. Globalization is a combination of free trade agreements, the integration of the Internet and financial markets that make the world a single and highly competitive market"[6,].

Scientific research by world scientists has given different definitions to the concept of "globalization" and continues to express different views and attitudes towards it. But the process of expressing the integrity of the globe and ensuring the "unity" of all spheres as a factor has always been paramount.

In particular, the Russian scientist I. Burikova considers globalization as a process and summarizes the views of scientists on it, showing three main aspects:

Aspects of knowledge - what is known about the process of globalization.

Emotional is how you approach information. 
CURRENT RESEARCH JOURNAL OF PEDAGOGICS 2(6): 131-136, June

2021 DOI: https://doi.org/10.37547/pedagogics-crjp-02-06-25

ISSN 2767-3278

(C)2021 Master Journals

\section{Crossref do) 81 Google}

Accepted 25thJune, 2021 \& Published 30 th June, 2021

Morality is what needs to be done.

There are many definitions of globalization, but we think that the French researcher B. Bandi describes it in detail. It emphasizes the threedimensional nature of the globalization process.

Globalization is a continuous historical process.

Globalization is a process of homogenization and universalization of the world

Globalization is the process of washing away national borders.

Of course, on the one hand, there are positive aspects to this process. For example, the rapid influx of science and technology in many countries is due to globalization. This has a positive impact on the development of their economic life and the living standards of the people. In this way, it contributes to the growth of the general intellectual potential of mankind.

On the other hand, the negative effects of globalization are obvious. In particular, the widening of economic disparities between developed and developing countries, especially through the use of modern telecommunications, computers, the Internet, the assimilation of national and spiritual values of a region to other peoples, and thus not only economic, but there are also attempts to establish national-spiritual domination. By the 21st century, this process has become more widespread than in the 20th century, increasing its influence, and, worst of all, many developed countries are strengthening economic integration in the world, assisting developing countries in science, technology, education, and promoting democratic values. under the pretext of widespread nationalspiritual influence. In this sense, the process of globalization serves the interests of more developed countries more than those of newly developed or developing countries.

Modern debates on globalization are exacerbating the problem and giving rise to new alternative theories. In particular, the French scientist Jacques Le Dumgy develops the following approaches:

Liberal approach. Globalization is not only an objective process, but also leads to economic, social efficiency as a beneficial phenomenon;

Cultural approach. The crisis of national cultures is the clash of historical societies, the emergence of "mixed culture" [7,].

In contrast to the above approaches, the Dutch researcher Y. N. Peters proposes the following typology of paradigms in his interpretation of globalization. Clash of Civilizations. Confrontation of countries of different cultures [8,]. So, because globalization is a multifaceted process, we have a lot of difficulty interpreting it. In order to overcome this, it is necessary to make a full and thorough analysis of the processes taking place in the world under the influence of globalization.

"Another peculiarity of the process of globalization is that in the current situation, it has become a very sharp tool of ideological influence, serving the interests of various political forces and centers. inevitable [9,] ". However, in the process of globalization, the national idea and ideology of each country plays a special role in the emergence of this immunity. of course, the basis of the ideology is love, devotion and trust in the motherland, peace and tranquility, which is the age-old dream of our ancestors, its preservation, strengthening and our centuries-old traditions. Ideological immunity emerges only when it is built on the goal of ensuring that our values and traditions are passed on to future generations.

Pros of globalization:

- The struggle of the peoples of the world for peace;

- Cooperation between different countries in the fields of economy, politics, science and 
CURRENT RESEARCH JOURNAL OF PEDAGOGICS 2(6): 131-136, June

2021 DOI: https://doi.org/10.37547/pedagogics-crjp-02-06-25

ISSN 2767-3278

(C)2021 Master Journals

\section{Crossref do) 81 Google}

Accepted 25th June, 2021 \& Published 30 $0^{\text {th }}$ June, 2021

technology, culture, education and others;

- fight against the arms race;

- fight against terrorism and drugs;

- combating epidemics of infectious diseases;

- Unconditional assistance from other countries to the population affected by natural disasters, such as earthquakes, floods, fires, volcanic eruptions, tsunamis, etc.

- Disadvantages of globalization:

- environmental problems, such as ozone depletion, global warming, deforestation, desertification, the Aral Sea tragedy, etc .;

- The spread of disease epidemics to different countries, especially AIDS;

- Increased terrorism and drug addiction;

- Threat to public morale.

- Poisoning the minds of young people, contrary to their own national values and traditions, and even more dangerous spirituality, the adoption of foreign culture as a "mass culture", inciting young people to draw conclusions in favor of the West. 'ymoq

- Expansion of arms and drug trafficking, etc.

The main reason why the process of globalization is entering our country, our life, is that today the development of any country is closely linked not only with its near and far neighbors, but also with other countries in the region. It is not difficult to understand that the exclusion of any country, including Uzbekistan, from this process will not lead to positive results. Just as there are pros and cons to every social phenomenon, there are pros and cons to the process of globalization that we need to understand with sensitivity.

The peculiarity of the process of globalization is that the actions in today's modern information space are so rapid that it happened so far away from us that it cannot be ignored that it has nothing to do with us. Another feature of the process of globalization is that it has become a sharp weapon of ideological influence, serving the interests of various political forces and centers.

As Karimov put it, "Ideological sites today are more powerful than nuclear sites." It is important to be aware that military, political and economic pressure can be felt and prevented, and ideological pressure can be very difficult to detect. In such a situation, a person cannot withstand all kinds of spiritual threats and hidden influences without his independent opinion, sound outlook and strong will [9,].

The President of the Republic of Uzbekistan Shavkat Mirziyoyev said in the parable of education: "We consider it our priority to improve the functioning of all segments of the education system in accordance with modern requirements." Shavkat Mirziyoyev also said in his speeches, "Speaking about the upbringing of the younger generation: I would very much like each of us, especially our sons and daughters, who are now coming to life, to follow the ideas of our grandfather Abdurauf Fitrat. . Here is what our great ancestor wrote: "People should strive for a specific goal, become rich, be happy and respected, be brave or weak, be humiliated, bear the burden of unhappiness, be neglected. , the subjugation and enslavement of others depends on the upbringing they received from their parents as children [10,] ».

Given the growing threat of religious extremism, terrorism, drug abuse, human trafficking, illegal migration, and "mass culture" around us today, the deeper meaning and significance of these words are even clearer. will be. Indeed, educating young people today is an issue that will never lose its relevance and importance. " Ideological threats and information attacks are a 
CURRENT RESEARCH JOURNAL OF PEDAGOGICS 2(6): 131-136, June

2021 DOI: https://doi.org/10.37547/pedagogics-crjp-02-06-25

ISSN 2767-3278

(C)2021 Master Journals

\section{Crossref do) 81 Google}

Accepted 25thJune, 2021 \& Published 30 th June, 2021

complex set of terrible threats that undermine such noble goals as building a free and prosperous life. The ideological threat is especially dangerous as it seeks to instill in our hearts and minds a completely alien, destructive worldview. (There are those who consider themselves to be the only representatives of the absolute truth.) They are those who pursue selfish political interests, far from truth and objectivity. If we do not fight against them consistently, it can entice our youth and turn them into people who do not care about their parents, their duties and responsibilities to the country [10,].

As we set ourselves the task of building a free and democratic society, our advice to young people is to encourage them to use the experience of developed countries in their pursuit of the global information space with a deep understanding of universal and democratic values. . Currently, the world's geopolitical, socio-economic, information and communication landscape is undergoing profound changes, and the conflict of different ideologies is becoming more acute. In this situation, the struggle against thought, against idea, against ignorance, against enlightenment is more important than ever.

Our young people must grow up to be people who have a deep understanding of their national identity, the world, and keep pace with the times. Then our youth will not be affected by the "call" of ignorant fanatics and notions of morality, nor ideas that are completely foreign to us.

There are also negative aspects of our lives, such as bad habits, selfishness and indifference, kinship and localism, corruption and selfishness, and disregard for others. We need to think about how to rid our society of such evils. Emphasis is placed on the importance of this important task for our society, especially the intelligentsia.

One of the worst things that can happen to our nation is jealousy. Envy is caused by jealousy, resentment, and jealousy. Jealousy is a disgusting habit. It is no coincidence that the hadiths say, "Beware of envying anyone, for envy will consume your good deeds as fire consumes firewood."

\section{REFERENCES}

1. The word of the people. January 25, 2020 .: Address of the President of the Republic of Uzbekistan to the Oliy Majlis

2. Karimov I. High spirituality is an invincible force. -T ..: Spirituality, 2008. 111 - bet.

3. Ochildiev A. Globalization and ideological processes. - $\mathrm{T}$.: Muharrir Publishing House, 2009. 64 p.

4. Danilov-Danilyan V.I. Sustainable development - the problem of human vision //. Science, Society, Man, Moscow, 2004. -143 p.

5. Otamuratov S. Globalization and the nation. T., Yangi asr avlodi, 2008. - $13 \mathrm{p}$

6. Kasovis A. Regionalization, Globalization and Nationalism // Alternative. 1999.04. P. 529.

7. Bogomolov BA Globalization: some approach to understanding the phenomenon. Vestn. MSU Ser. 12. Political sciences. 2004. No. 3.

8. Bogomolov BA Globalization: some approach to understanding the phenomenon. Vestn. MSU Ser. 12. Political sciences. 2004. No.

9. Karimov I. High spirituality is an invincible force. - T ..: Spirituality, 2008. 113- bet.

10. Sh. Mirziyoyev. "The rule of law and the interests of the people are the key to the development of the country and the wellbeing of the people." T:. "Uzbekistan" 2017. B 22-23. 
CURRENT RESEARCH JOURNAL OF PEDAGOGICS 2(6): 131-136, June

2021 DOI: https://doi.org/10.37547/pedagogics-crjp-02-06-25

ISSN 2767-3278

(C)2021 Master Journals

Crossref dof 81 Google

Accepted 25thJune, 2021 \& Published 30th June, 2021

11. Shomirzayev, M. K. (2020). Developing Educational Technologies In School Technology Education. The American Journal of Engineering and Technology, 2(07), 51-57.

12. Shomirzayev, M.Kh. (2020). "Technology" In Secondary Schools Organization of Science Classes. The American Journal of Social Science and Education Innovations, Impact Factor 5.525 (11). -P. 395-405. 